\title{
Isolation of an Unusual 2-Aminoimidazolium Salt of Steroid Trisulfate from a Marine Sponge Topsentia sp.
}

\author{
Sachiko Tsukamoto, Haruko Kato, Hiroshi Hirota, \\ and Nobuhiro Fusetani ${ }^{\dagger}$
}

Fusetani Biofouling Project, Exploratory Research for Advanced Technology (ERATO), Research Development Corporation of Japan (JRDC), c/o Niigata Engineering Co., Ltd., Isogo, Yokohama 235, Japan

(Received August 12, 1996)

\begin{abstract}
An unusual salt comprised of three 2-aminoimidazolium cations and halistanol sulfate anion was isolated from a marine sponge Topsentia sp. along with known halistanol trisodium salt. Their structures were determined by spectroscopic methods. The number of 2 -aminoimidazolium ions in the molecule was estimated from the signal intensity in the ${ }^{1} \mathrm{H}$ NMR spectrum, and that of sodium ions was from the atomic absorption spectrometry. This is the first report of a unique salt consisted of 2-aminoimidazolium cations in natural source. Both halistanol sulfate salts showed antimicrobial activities against Flavobacterium marinotypicum and Mortierella ramaniana at $10 \mu \mathrm{g} /$ disk.
\end{abstract}

Key words: 2-aminoimidazole, antibacterial activity, antifungal activity, halistanol sulfate, marine sponge, Topsentia sp.

Marine sponges of the families Halichondriidae, Adociidae, and Axinellidae often contain steroid sulfates which possess a variety of bioactivities, such as antimicrobial, ${ }^{1,2)}$ anti-thrombin," HIV-inhibitory, ${ }^{3)}$ guanosine diphosphate/G-protein RAS exchange inhibitory, ${ }^{5}$ and tyrosine kinase inhibitory ${ }^{9}$ activities.

During our studies on antimicrobial substances in marine invertebrates, ${ }^{7,8)}$ we found that the $\mathrm{MeOH}$ extract of a marine sponge Topsentia sp. inhibited growth of the bacterium Flavobacterium marinotypicum and the fungus Mortierella ramaniana. Bioassay-guided isolation afforded a known trisodium salt, halistanol sulfate 1 , and an unusual tri-2-aminoimidazolium halistanol sulfate 2 (Fig. 1).

\section{Materials and Methods}

Infrared spectrum was measured with a JASCO IR-700 spectrometer. ' $\mathrm{H}$ and ${ }^{13} \mathrm{C}$ NMR spectra were recorded on a Bruker ARX-500 NMR spectrometer at $27^{\circ} \mathrm{C}$ in $\mathrm{MeOH}-d_{4}$ or DMSO- $d_{6}$. Carbon multiplicities were determined by a DEPT spectrum. Mass spectra were measured on a JEOL SX-102A mass spectrometer. Atomic absorption spectrum was obtained with a Hitachi Z-8100 polarized Zeeman atomic spectrophotometer.

\section{Collection and Extraction}

The marine sponge was collected by scuba at a depth of $3 \mathrm{~m}$ off Hachijo-jima Island and identified as Topsentia sp. (family Halichondriidae) by Dr. Rob van Soest. A voucher specimen (ZMA POR. 11062) was deposited at the Institute for Systematics and Population Biology, University of Amsterdam. The frozen sponge $(1.1 \mathrm{~kg}$, wet weight) was extracted with $\mathrm{MeOH}(1 l \times 3)$. The concentrated aque- ous residue was successively extracted with $\mathrm{Et}_{2} \mathrm{O}(1 / \times 3)$ and $n-\mathrm{BuOH}(1 l \times 3)$.

Isolation of Tri-2-aminoimidazolium Halistanol Sulfate

The $n$-BuOH layer $(2.90 \mathrm{~g})$ was fractionated by reversephase column chromatography on YMC-GEL ODS-A 60400/230 (Yamamura Chem. Co., Ltd., Kyoto, $2.2 \times 30$ cm) with 30,60 , and $80 \% \mathrm{MeOH}-\mathrm{H}_{2} \mathrm{O}$ and $\mathrm{MeOH}$ (each $300 \mathrm{ml}$ ). The second and third fractions were separately purified on Sephadex LH-20 (Pharmacia, $2.2 \times 70 \mathrm{~cm}$, $\mathrm{MeOH}, 2.0 \mathrm{ml} / \mathrm{min}$ ) followed by reverse-phase column chromatography $\left(1.1 \times 25 \mathrm{~cm}, 25 \% \mathrm{CH}_{3} \mathrm{CN}-\mathrm{H}_{2} \mathrm{O}\right.$ containing $0.01 \%$ TFA, $1.0 \mathrm{ml} / \mathrm{min}$ ) to afford tri-2-aminoimidazolium halistanol sulfate $(2,70.9 \mathrm{mg}, 0.025 \%$ based on wet weight) and the trisodium salt, halistanol sulfate (1, $67.1 \mathrm{mg}, 0.024 \%$ ), respectively.

Halistanol Sulfate 1: FABMS (negative) see Fig. 2.

Tri-2-aminoimidazolium Halistanol Sulfate 2: IR (film) $v_{\max } 3300,3160,2940,1680,1220$, and $1060 \mathrm{~cm}^{-1} .{ }^{1} \mathrm{H}$ NMR (DMSO- $\left.d_{6}\right) \delta 3.80(1 \mathrm{H}, \mathrm{dt}, J=11$ and $4 \mathrm{~Hz}, \mathrm{H}-6)$, $4.26(1 \mathrm{H}$, br s, H-3), $4.42(1 \mathrm{H}$, br s, H-2), $6.85(6 \mathrm{H}, \mathrm{s}$, olefin protons of 2-aminoimidazolium units), $7.30(6 \mathrm{H}, \mathrm{br}$ $\mathrm{s}, \mathrm{NH}$ of 2-aminoimidazolium units), and $11.72(6 \mathrm{H}$, br s, $\mathrm{NH}_{2}$ of 2-aminoimidazolium units). $\left.{ }^{13} \mathrm{C} \mathrm{NMR} \mathrm{(MeOH}-d_{4}\right)$ $\delta 12.5$ (q), $15.0(\mathrm{q}), 15.4(\mathrm{q}), 19.6(\mathrm{q}), 21.8(\mathrm{t}), 25.1(2 \mathrm{C}, \mathrm{t})$, $27.8(3 \mathrm{C}, \mathrm{q}), 29.1(\mathrm{t}), 29.3(\mathrm{t}), 34.0(\mathrm{~s}), 35.1(\mathrm{~d}), 36.6(\mathrm{t})$, $37.7(\mathrm{~d}), 37.7(\mathrm{~s}), 39.0(\mathrm{t}), 40.0(\mathrm{t}), 41.1(\mathrm{t}), 43.8(\mathrm{~s}), 45.4(2$ C, d), 55.8 (d), 57.3 (d), 57.5 (d), 75.7 (d), 75.6 (d), 78.9 (d), 114.4 (6 C, d), and 148.7 (3 C, s). FABMS (positive, glycerol matrix) $m / z 84$ (M as 2 -aminoimidazolium ion) ${ }^{+}$. FABMS (negative) see Fig. 2.

\footnotetext{
${ }^{\dagger}$ Corresponding author.
} 


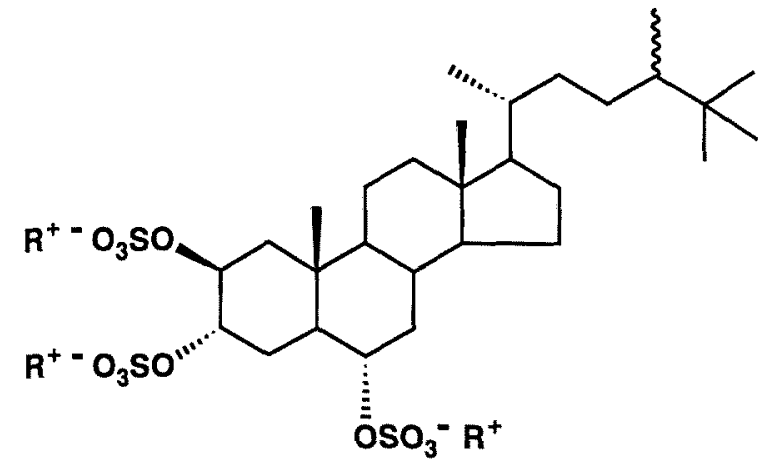

1 (Halistanol sulfate): $\mathrm{R}^{+}=\mathrm{Na}^{+}$<smiles></smiles>

Fig. 1. Structures of antimicrobial substances.
Separation of the Steroidal and 2-Aminoimidazole Units of 2

Compound $2(12.7 \mathrm{mg})$ was applied onto a cation exchange HPLC column (YMC-Pack IES-AX, 4.6× 250 $\mathrm{mm}$, Yamamura Chem. Co., Ltd., Kyoto) and eluted with $50 \mathrm{mM}$ triethylamine-formic acid (pH 5.49) $(1.0 \mathrm{ml} / \mathrm{min})$ to afford an 2-aminoimidazole unit $(3.0 \mathrm{mg})$. Then, the steroidal unit $(7.3 \mathrm{mg})$ was eluted with $50 \% \mathrm{MeOH}-\mathrm{H}_{2} \mathrm{O}$ containing $1 \mathrm{M} \mathrm{NaCl}$ followed by desalting.

\section{Determination of Antimicrobial Activity}

Antimicrobial activity was determined by the paper disk method. Paper disks (thick, $8 \mathrm{~mm}$, Toyo Roshi Kaisha, Ltd., Tokyo) impregnated with each $10 \mu \mathrm{g}$ of samples were placed on agar plate containing $F$. marinotypicum ATCC 19260 or $M$. ramaniana, and the plate was incubated for $24 \mathrm{~h}$ at $28^{\circ} \mathrm{C}$.

\section{Results}

Two antimicrobial compounds 1 and 2 were isolated from the $\mathrm{MeOH}$ extract of a marine sponge Topsentia sp. Compound 1 was readily identified as halistanol sulfate (Fig. 1) by comparison of spectral data with those in literature, ${ }^{1)}$ and the number of sodium ions was determined by atomic absorption spectrometry; composition of sodium, potassium, and magnesium ions in 1 was $7.66,0.39$, and $0.02 \%$, respectively, indicating that more than two and half molecules of the cation in 1 consisted of sodium ions.

${ }^{13} \mathrm{C}$ NMR data clearly revealed that 2 consisted of a steroidal moiety of halistanol sulfate 1, supported by an intense IR band at $1220 \mathrm{~cm}^{-1}$ and pseudomolecular ion peaks at $m / z 731$ and 709 in the negative FAB mass spectrum (Fig. 2). The additional ${ }^{13} \mathrm{C}$ signals at $\delta 114.4(6 \mathrm{C}$, d) and $148.7(3 \mathrm{C}, \mathrm{s})$ and ${ }^{1} \mathrm{H}$ signals at $\delta 6.85(6 \mathrm{H}, \mathrm{s}$, olefin protons), $7.30(6 \mathrm{H}, \mathrm{br} \mathrm{s}, \mathrm{NH})$, and $11.72\left(6 \mathrm{H}, \mathrm{br} \mathrm{s}, \mathrm{NH}_{2}\right)$
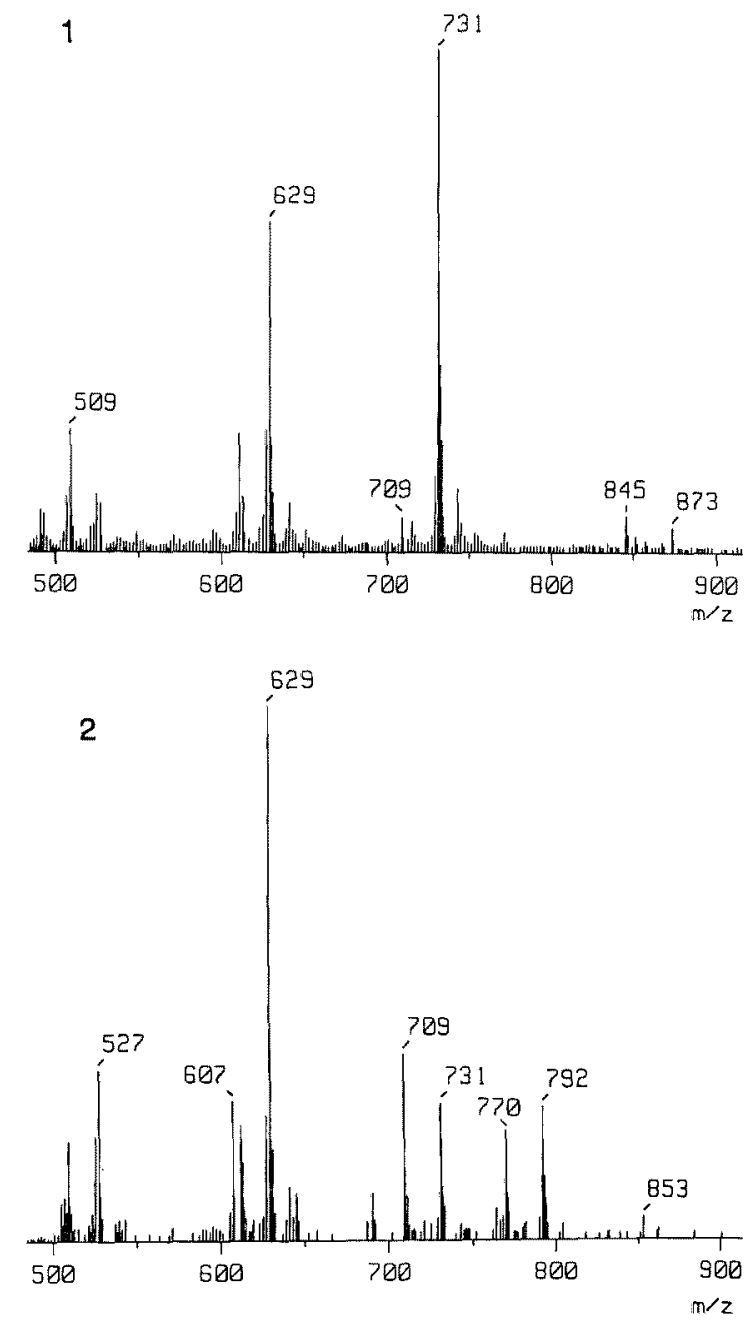

Fig. 2. FAB mass spectra (negative mode) of trisodium halistanol sulfate 1 and tri-2-aminoimidazolium halistanol sulfate 2 .

1: (glycerol matrix) $m / z 731$ (M as steroidal part $+2 \times \mathrm{Na})^{-}, 709$ $(\mathrm{M}+\mathrm{Na}+\mathrm{H})^{-}$, and $629\left(709-\mathrm{SO}_{3}\right)^{-}, 2:(\mathrm{NBA}$ matrix) $\mathrm{m} / z 853(\mathrm{M}$ as steroidal part $+2 \times 2$-aminoimidazolium ion) ${ }^{-}, 792(\mathrm{M}+2$-aminoimidazolium ion $+\mathrm{Na})^{-}, 770(\mathrm{M}+2 \text {-aminoimidazolium ion }+\mathrm{H})^{-}$, $731(\mathrm{M}+2 \times \mathrm{Na})^{-}, 709(\mathrm{M}+\mathrm{Na}+\mathrm{H})^{-}, 629\left(709-\mathrm{SO}_{3}\right)^{-}, 607$ $(629-\mathrm{Na}+\mathrm{H})^{-}$, and $527\left(607-\mathrm{SO}_{3}\right)^{-}$.

suggested the presence of three moles of 2-aminoimidazole units in 2 (Fig. 1), which was also supported by IR bands at $3300(\mathrm{~N}-\mathrm{H}$ stretch), $3160(\mathrm{~N}-\mathrm{H}$ stretch), $1680(\mathrm{~N}-\mathrm{H}$ bend), and $1060 \mathrm{~cm}^{-1}(\mathrm{C}-\mathrm{N}$ stretch) and a molecular ion peak at $m / z 84$, coinciding with 2-aminoimidazolium ion, in positive FAB mass spectrum. The ${ }^{1} \mathrm{H}$ NMR spectra of the steroidal and 2-aminoimidazole units of 2 which had been separated on an ion exchange column were superimposable on those of 1 and the commercially available 2aminoimidazole sulfate (Aldrich Chem. Co., Inc.), respectively. Thus, the gross structure of 2 was established (Fig. 1). Interestingly, the negative $F A B$ mass spectra of 1 and 2 implied their ion composition (Fig. 2); 1 showed prominent pseudo- and desulfonated-molecular ion peaks at $\mathrm{m} /$ $z 731$ and 629 , respectively, while 2 revealed additional peaks comprising one or two 2 -aminoimidazole unit(s) at 
$m / z 770,792$, and 853 .

Compounds 1 and 2 showed the similar antimicrobial activities: 9 and $12 \mathrm{~mm}$ of growth inhibitory zones against $F$. marinotypicum and $M$. ramaniana at $10 \mu \mathrm{g} /$ disk, respectively. Incidentally, 2-aminoimidazole sulfate (Aldrich Chem. Co., Inc.) was inactive.

\section{Discussion}

It is noteworthy that tri-2-aminoimidazolium salt 2 and trisodium salt 1 of halistanol sulfate co-occurred in the present marine sponge. Similar examples have been reported: $\beta$-carbolinium salts, reticulatines $\mathrm{A}$ and $\mathrm{B}^{\text {9) }}$ composed of different anions; and $(E)$ - and $(Z)$-narains, $N, N$ dimethylguanidinium styryl sulfates. ${ }^{10}$ )

Steroid sulfates including halistanol sulfate ${ }^{1)}$ and halistanol sulfates $\mathrm{A}-\mathrm{H}^{3,4)}$ have been isolated as trisodium salts except for echinoclasterol sulfate phenethylammonium salt. ${ }^{2)}$ 2-Aminoimidazole-containing metabolites have been reported from a variety of marine invertebrates. ${ }^{11-13)}$ Tri-2-aminoimidazolium halistanol sulfate 2 , however, is the first report of a unique 2-aminoimidazolium salt of natural product.

Acknowledgments We are indebted to Prof. I. Kitagawa of Kinki University for valuable discussions, to Dr. $R$. van Soest of the University of Amsterdam for identification of the sponge, and to Dr. H. Onuki of Nippon Suisan Kaisha, Ltd. for the measurement of the atomic absorption spectrometry.

\section{References}

1) N. Fusetani, S. Matsunaga, and S. Konosu: Bioactive marine metabolites II. Halistanol sulfate, an antimicrobial novel steroid sulfate from the marine sponge Halichondria cf. moorei Bergquist. Tetrahedron Lett., 22, 1985-1988 (1981).

2) H.-y. Li, S. Matsunaga, N. Fusetani, H. Fujiki, P. T. Murphy, R.
H. Willis, and J. T. Baker: Echinoclasterol sulfate phenethylammonium salt, a unique steroid sulfate from the marine sponge Echinoclathria subhispida. Tetrahedron Lett., 34, 5733-5736 (1993).

3) S. Kanazawa, N. Fesetani, and S. Matsunaga: Halistanol sulfates A-E, new steroid sulfates, from a marine sponge, Epipolasis sp. Tetrahedron, 48, 5467-5472 (1992).

4) G. Bifulco, I. Bruno, L. Minale, and R. Riccio: Novel HIV-inhibitory halistanol sulfates F-H from a marine sponge, Pseudoaxinissa digitata. J. Nat. Prod., 57, 164-167 (1994).

5) S. P. Gunasekera, S. H. Sennett, M. Kelly-Borges, and R. W. Bryant: Ophirapstanol trisulfate, a new biologically active steroid sulfate from the deep water marine sponge Topsentia ophiraphidites. J. Nat. Prod., 57, 1751-1754 (1994).

6) D. L. Slate, R. H. Lee, J. Rodriguez, and P. Crews: The marine natural product, halistanol trisulfate, inhibits p $60^{\mathrm{v}-\mathrm{src}}$ protein tyrosine kinase activity. Biochem. Biophys, Res. Commun., 203, 260264 (1994).

7) S. Tsukamoto, H. Hirota, H. Kato, and N. Fusetani: Isolation of ejcosapentaenoyl and arachidonoyl lysophosphatidylinosítols from the ascidian Halocynthia roretzi (v. Drasche). Comp. Biochem. Physiol., 106C, 151-153 (1993).

8) S. Tsukamoto, H. Kato, H. Hirota, and N. Fusetani: Antibacterial and antifungal sulfated alkane and alkenes from the hepatopan. creas of the ascidian Halocynthia roretzi. J. Nat. Prod., 57, 16061609 (1994).

9) C. Jimenez, E. Quinoa, and P. Crews: Novel marine sponge alkaloids 3. $\beta$-Carbolinium salts from Fascaplysinopsis reticulata. Tetrahedron Lett., 32, 1843-1846 (1991).

10) S. Tsukamoto, H. Kato, H. Hirota, and N. Fusetani: Narains: $N, N$-dimethylguanidinium styryl sulfates, metamorphosis inducers of ascidian larvae from a marine sponge Jaspis sp. Tetrahedron Lett., 35, 5873-5874 (1994).

11) S. Forenza, L. Minale, R. Riccio, and E. Fattorusso: New bromopyrrole derivatives from the sponge Agelas oroides. J. Chem. Soc., Chem. Commun., 1129-1130 (1971).

12) E. E. Garcia, L. E. Benjamin, and R. Ian Fryer: Reinvestigation into the structure of oroidin, a bromopyrrole derivative from marine sponge. J. Chem. Soc., Chem. Commun., 78-79 (1973).

13) L. Cariello, S. Crescenzi, G. Prota, and L. Zanetti: Zoanthoxanthins of a new structural type from Epizoanthus arenaceus (Zoantharia). Tetrahedron, 30, 4191-4196 (1974). 